\title{
Talk about the New Product Development Strategy from the Innovation Level
}

\author{
Xuesheng Pei \\ School of Art and Design, \\ Henan University of Science and Technology, \\ Luoyang, China \\ Pxsh12@126.com
}

\begin{abstract}
The reasonable product development strategy is the key to business. This paper analyzes the characteristics of innovation levels on the difference impact for society and analyzes the financial and other conditions to achieve innovation. According to different technical conditions and different scale of enterprises, enterprises adopt suitable innovation levels in the face of the fierce market competition, and formulate a realistic new products strategy. Through launching new products or increasing the variety of products to existing market. Enterprise will effectively solve the problem of how to position; to expand market share and increase sales. It is more conducive to develop different enterprises according to their own advantage, reduce the management risk of the enterprise, and promote the healthy growth of enterprises.
\end{abstract} design

Keywords- innovation; products; strategy; position; industrial

\section{INTRODUCTION}

Innovation of science and technology is the strategic support to improve the social productivity and the comprehensive national strength, the core position in the national overall development. To adhere to the Chinese characteristics road of independent innovation, and promote innovation with a global perspective plan, improve the ability of original innovation, integrated innovation and the introduction, digestion and absorption of re-innovation, pay more attention to the collaborative innovation." New product development strategy is very important for the business. Foreign scholars have lots of research in the field, and put forward 4 stages, 6 stages at different stages of the model. [1] In these models, from the product concept to the market, innovation always is paid attention.

The new product development strategy is the roadmap and the guide direction of enterprise product development. Product development strategy is based on the market values and social attitudes, enterprises to provide new products to the existing market, to meet customer needs, a kind of strategy for increasing sales. Product development strategy is the enterprise choices and decisions when they in the face of market opportunities and challenges after internal resource advantages and disadvantages of comprehensive, forward thinking and understanding in new product development.

Many scholars have conducted in-depth research on new product development strategy. Z.Y. Hou [1] presents a method of network analytic process, effectively help enterprises to choose the strategy of new products. J. Xu [1] presents the application of SWOT in the product development strategy analysis, represent respectively: strengths, weaknesses, opportunities, threats, to make the complex information clear. For the division of product development strategy, the scholars have different views. P. Wang [1]according to the degree of novelty product development on new product development strategy for classification, there are four kinds of strategic choice: new, replacement type, improved, the generic type of new product development strategy. But no one discusses the new product development strategy from the innovation perspective.

\section{LEVEL OF INNOVATION}

According to the degree of innovation and the social impact, product innovation can be divided into product concept innovation, technology innovation, formal innovation, structure innovation, production process innovation etc.

\section{A. The Innovation of Product Concept}

The innovation of product concept is the highest level of innovation. The new product with broad market prospects is presented by the relevant persons (including designers, managers, sellers, consumers etc.) according to the market research data and information. Innovation of the level always showed invention. New concept product can fill the market blank and guide the social demand. Such as mobile phone, computer, washing machine and other products concept have great influence on the society, and new industry and a large number of new enterprises had been created.

\section{B. Technological Innovation}

In order to make the products reach the leading level. Existing technologies are used for combinatorial innovation, or new technologies are researched for tackling the problem after the new product concept had presented. Such as energy-saving technology, new materials, surface treatment technology, production process technology, control technology, software and other aspects of innovation research. Innovation of the level mostly showed invention, copyright etc.

\section{Forms Innovation}

Using disciplines of aesthetics, psychology, engineering and other subjects, the feeling elements of the product (such as shape, color, pattern, material and other aspects) are designed, 
so as to create new forms, in order to meet people's enjoyment of the senses. Innovation results mostly showed design patent.

\section{Structure Innovation}

The partial or whole structures of the product are re-designed by using modern design method. So that the product structures are more reasonable, better performance and higher quality. [4]. The innovation results mostly showed the utility models.

\section{E. Technological Innovation}

The manufacturing process improvement of the product can ensure the production have a low cost, high efficiency, stable quality. The innovation results mostly showed the technical secret.

\section{F. Other Innovations}

The innovation of the management, marketing methods and means can also play a huge role in promoting to improve enterprise efficiency.

\section{THE REQUIREMENTS OF INNOVATION LEVEL TO THE ENTERPRISE.}

According to the division of innovation level, it can be seen that the achievement of different innovation level is not the same and the benefits they can bring for the enterprise are also different. However, the requirements of different innovation level to the investment of the enterprise and the competence of personnel are not the same.

In the first level-concept innovation, participants of innovation are required to have rich knowledge and can analyze demand and potential demand of user accurately through market research and provide decision makers with product concept that they form. Once the decision to implement the concept of new products is made, enterprises must be prepared to adequate funding, the purchase of the corresponding equipment, tools and raw materials for production. For new products, the market acceptance must have a process, so they have to have a good performance in marketing after sale service. The knowledge structure of enterprise participants of innovation includes statistics, consumer psychology, design science, engineering technology and so on.

In second levels-technological innovation, enterprise must have a certain number of engineering and technical personnel, who can complete the research on new technology of a field associated with the enterprise through science and technology. For the implementation of the new technology, enterprises need to have more funds for protection and the purchase of new equipment to meet the requirements. The knowledge structure of the enterprise professionals is required to include engineering technology knowledge, value engineering and so on.

In the third level-form Innovation, the enterprise required to create new products in the base of existing technology by changing the product form. Input requirement of the enterprise in this way is relatively low, it mainly rely on the industrial designer to complete the corresponding working content. Designers are required to design the product form in line with the market requirements firstly, and provide the design basis for the later design. The knowledge structure of technical personnel includes aesthetics, psychology, semiotics, mechanical engineering and so on.

In fourth level-structure innovation, the enterprise is required to analyze the function of the product carefully, under the condition of guarantee product function, optimizing design the product structure form with the superior performance, and construct three-dimensional parts. This innovation can effectively improve product performance, in the process of competition with rivals, and win more market share. The requirement of the technical personnel is that they can conduct in-depth communication between engineers, provide the design basis for the later period manufacture. The knowledge structure of technical personnel is required to include mathematics, mechanics, technology, materials science and so on.

In the fifth level-technology innovation, the enterprise is required to explore new production process and methods through the internal potential, so as to improve the production efficiency, stabilize production quality, reduce production cost. This innovation requires less investment to the enterprise but benefit is obvious. The knowledge structure of technical personnel is required to include technology, materials science, industrial engineering and so on.

In other areas of innovation, enterprises may also rely on creative thinking, and put forward some innovative methods in order to improve the enterprise management level and economic efficiency.

\section{THE CHOICE OF ENTERPRISE'S NEW PRODUCT DEVELOPMENT STRATEGY}

There is a big difference between the different sizes of the enterprise, and personnel configuration is also very different. The enterprise should choose different new product development strategy according to their actual situation, combining with product innovation level.

\section{A. The Guiding Strategy}

This strategy requires that enterprises are in the concept innovation level, and pursue the use of innovative products, guide consumers to pursue a new operation experience satisfaction, open up a new market, through the market investigation and analysis, using creative thinking of the relevant personnel. Of course, it requests that the enterprise has very strong ability of research and development and the abundant resources.

\section{B. The Leading Strategy}

This strategy requires that enterprises are in the technological innovation level, and maintain the sustaining advantage in technology and the leading position in the market competition. It also requests that the enterprise has a strong research and development capability and more resources. The main countermeasures are that the company research and development continuously, and maintain the leading technology, create differentiated products by the new leading technology, launch new surprising products to customers continuously, occupy the market by leading listed; new 
product development must pay attention to speed limitation, development speed, development cycle.

\section{The Improved Strategy}

When the enterprises compete with others, in order to improve the market competitiveness and reduce costs effectively, they can adopt the strategy of structural innovation, process innovation, to compete the market with excellent performance, price advantage. Take this strategy, it requests enterprises not to study new product before others, but meet regularly to track the information of market changes. According to the product's life cycle stages, timely to improve, expand market share. This strategy requires enterprises to have certain research and development ability and resources.

\section{The Variation Strategy}

When the enterprise is in the same level in technology and production processes with other competitors, in order to enhance the market competitiveness, the form innovation strategy can be adopted. On the basis of the pursuit of perfect quality, different forms of products are designed with customer demand-oriented, according to different people. Different requirements of consumers are satisfied with the personality characteristics. This strategy requires enterprises to have very strong industrial design ability and certain resources.

\section{E. The Introduction of Development Strategy}

In order to improve the product market share and economic benefit of enterprise, as a criterion, enterprises refer to research and development of other units for value, instead of their own research and development of new products, according to the actual situation of enterprises. The enterprise with the limited resources whose research and development strength is not strong should adopt the strategy.

When enterprises are in the practical application of the new product development strategy, they should choose the right development strategy according to the actual situation of enterprise technical force and resource guarantee, and sometimes it can also be mixed with other kinds of the product development strategy in order to facilitate the enterprise long-term survival and development.

\section{CONCLUSION}

To sum up, new product development strategy of the enterprise is located according to the innovation level. It can not only solve the problem how to survive, but also be conducive to different enterprises to participate in the characterization of market competition according to their own advantages, increase market share, improve efficiency, promote the rapid development of the enterprise.

\section{REFERENCES}

[1] F.Z. Xu, H.X. Yang, P.T. Gao, "Foreign enterprises on product development strategy”, Science \& Technology Progress and Policy, pp 149-155, January 2010

[2] Z.Y. Hou, S.X. Zhang, "New product development strategy of analytic network process ”, Business managers, November 2012, pp 176

[3] J. Xu, "Product strategy decision theory in the enterprise product development strategy in the role and achievements", Business review, March 2013,pp 83
[4] P. Wang, "On the product development strategy", Chinese business, April 2010,pp 242-243 